NBER WORKING PAPER SERIES

INVESTMENT SHOCKS AND BUSINESS CYCLES

\author{
Alejandro Justiniano \\ Giorgio E. Primiceri \\ Andrea Tambalotti \\ Working Paper 15570 \\ http://www.nber.org/papers/w15570
}
NATIONAL BUREAU OF ECONOMIC RESEARCH
1050 Massachusetts Avenue
Cambridge, MA 02138

December 2009

We wish to thank Pedro Amaral, Mark Gertler, Nicolas Groshenny, Lee Ohanian, Andrea Raffo, Juan Rubio-Ramirez, Frank Schorfheide, Thijs van Rens, Raf Wouters, an anonymous referee and participants to many seminars and conferences for comments and suggestions. We would also like to thank Frank Smets and Raf Wouters for sharing their codes and data. The views in this paper are solely the responsibility of the authors and should not be interpreted as reflecting the views of the Federal Reserve Bank of Chicago, the Federal Reserve Bank of New York, any other person associated with the Federal Reserve System, or the National Bureau of Economic Research.

NBER working papers are circulated for discussion and comment purposes. They have not been peerreviewed or been subject to the review by the NBER Board of Directors that accompanies official NBER publications.

(C) 2009 by Alejandro Justiniano, Giorgio E. Primiceri, and Andrea Tambalotti. All rights reserved. Short sections of text, not to exceed two paragraphs, may be quoted without explicit permission provided that full credit, including (C) notice, is given to the source. 
Investment Shocks and Business Cycles

Alejandro Justiniano, Giorgio E. Primiceri, and Andrea Tambalotti

NBER Working Paper No. 15570

December 2009

JEL No. C11,E3,E32

\begin{abstract}
We study the driving forces of fluctuations in an estimated New Neoclassical Synthesis model of the U.S. economy with several shocks and frictions. In this model, shocks to the marginal efficiency of investment account for the bulk of fluctuations in output and hours at business cycle frequencies. Imperfect competition and, to a lesser extent, technological frictions are the key to their transmission. Labor supply shocks explain a large fraction of the variation in hours at very low frequencies, but are irrelevant over the business cycle. This is important because their microfoundations are widely regarded as unappealing.
\end{abstract}

\author{
Alejandro Justiniano \\ Economic Research Department \\ Federal Reserve Bank of Chicago \\ 230 S. LaSalle Street \\ Chicago, IL 60604 \\ Alejandro.Justiniano@chi.frb.org \\ Giorgio E. Primiceri \\ Department of Economics \\ Northwestern University \\ 3218 Andersen Hall \\ 2001 Sheridan Road \\ Evanston, IL 60208-2600 \\ and NBER \\ g-primiceri@northwestern.edu
}

Andrea Tambalotti

Federal Reserve Bank of New York

33 Liberty Street, 3rd Floor

New York, NY 10045

Andrea.Tambalotti@ny.frb.org 


\title{
INVESTMENT SHOCKS AND BUSINESS CYCLES
}

\author{
ALEJANDRO JUSTINIANO, GIORGIO E. PRIMICERI, AND ANDREA TAMBALOTTI
}

Abstract. We study the driving forces of fluctuations in an estimated New Neoclassical Synthesis model of the U.S. economy with several shocks and frictions. In this model, shocks to the marginal efficiency of investment account for the bulk of fluctuations in output and hours at business cycle frequencies. Imperfect competition and, to a lesser extent, technological frictions are the key to their transmission. Labor supply shocks explain a large fraction of the variation in hours at very low frequencies, but are irrelevant over the business cycle. This is important because their microfoundations are widely regarded as unappealing.

\section{Introduction}

What is the source of economic fluctuations? This is one of the defining questions of modern dynamic macroeconomics, at least since Sims (1980) and Kydland and Prescott (1982). Yet, the literature has not reached a consensus on the answer. On the one hand, the work that approaches this question from the perspective of general equilibrium models tends to attribute a dominant role in business cycles to neutral technology shocks (see King and Rebelo (1999) for a comprehensive assessment). On the other hand, the structural VAR literature usually points to other disturbances as the main sources of business cycles, and rarely finds that neutral technology shocks explain more than one quarter of output fluctuations (Shapiro and Watson (1988), King, Plosser, Stock, and Watson (1991), Cochrane (1994), Gali (1999), Christiano, Eichenbaum, and Vigfusson (2004) and Fisher (2006)).

We revisit this debate from the perspective of a New Neoclassical Synthesis model of the US economy (Goodfriend and King (1997)), estimated with Bayesian methods. The model adds to a neoclassical core a rich set of nominal and real frictions, along the lines of Christiano, Eichenbaum, and Evans (2005), and several shocks, as in Smets and Wouters (2007).

Date: First version: November 2007. This version: November 2009. We wish to thank Pedro Amaral, Mark Gertler, Nicolas Groshenny, Lee Ohanian, Andrea Raffo, Juan Rubio-Ramirez, Frank Schorfheide, Thijs van Rens, Raf Wouters, an anonymous referee and participants to many seminars and conferences for comments and suggestions. We would also like to thank Frank Smets and Raf Wouters for sharing their codes and data. The views in this paper are solely the responsibility of the authors and should not be interpreted as reflecting the views of the Federal Reserve Bank of Chicago, the Federal Reserve Bank of New York or any other person associated with the Federal Reserve System. 
Among them, a shock to total factor productivity (or neutral technology shock), as in the $\mathrm{RBC}$ literature; a shock to the marginal productivity of investment (or, for simplicity, investment shock), as in Greenwood, Hercowitz, and Huffman (1988); and a shock to desired wage markups (or, equivalently, to labor supply), as in Hall (1997). This model is an ideal laboratory to study the driving forces of fluctuations, for three reasons. First, its fit is competitive with that of unrestricted VARs (Smets and Wouters (2007), Del Negro, Schorfheide, Smets, and Wouters (2007)). Second, it encompasses within a general equilibrium framework most of the views on the sources of business cycles found in the literature. ${ }^{1}$ Third, its deviations from the neoclassical growth prototype give disturbances other than the neutral technology shock a fair chance to be plausible cyclical forces.

In the estimated model, investment shocks account for between 50 and 60 percent of the variance of output and hours at business cycle frequencies and for more than 80 percent of that of investment. The contribution of neutral technology shocks is smaller, but not negligible. They explain about a quarter of the movements in output and consumption, although only about 10 percent of those in hours. These numbers are close to those estimated by Fisher (2006) within a structural VAR.

Labor supply shocks are irrelevant over the business cycle, although they dominate the fluctuations of hours at very low frequencies. This finding is important because labor supply shocks are a key ingredient of many business cycle models, but many economists find them intellectually unappealing (see Chari, Kehoe, and McGrattan (2008) and especially Shimer (2009) for an extensive discussion and references). According to our results, these disturbances can be ignored when studying business cycles, although they are necessary to account for the low level of hours worked in the seventies and early eighties.

Other papers in the literature study the sources of fluctuations in empirical medium-scale DSGE models. In particular, Smets and Wouters (2007) present an analysis of the driving forces of output as one of the applications of their estimated model of the U.S. economy. In contrast to our results, however, they conclude that "it is primarily two "supply" shocks, the productivity and the wage mark-up shock, that account for most of the output variations in the medium to long run," while they find almost no role for the investment shocks beyond the shortest horizons.

\footnotetext{
${ }^{1}$ We do not analyze the role of news shocks, which have recently received much attention in the literature (e.g. Beaudry and Portier (2006) and Jaimovich and Rebelo (2009))
} 
We show that these conclusions depend on the unusual definition of consumption and investment adopted by Smets and Wouters (2007). They include durable expenditures in consumption, while excluding (the change in) inventories from investment, although not from output. When investment is defined as including inventories, but especially durables, as in most of the literature, it becomes more volatile and more procyclical. Consequently, investment adjustment costs decline substantially and the investment shock becomes the fundamental driving force of fluctuations at business cycle frequencies. To demonstrate that these conclusions are not the product of an arbitrary measurement choice, we also estimate a model with an explicit role for durable consumption goods in home production, as in Greenwood and Hercowitz (1991). In this model, investment shocks account for an even larger share of the business cycle variance of output and hours than in the baseline.

In another closely related paper, Justiniano and Primiceri (2008) find that investment shocks are the main contributors to the Great Moderation in output. Moreover, according to their estimated DSGE model with time varying volatilities, the share of the variance of output growth accounted for by investment disturbances oscillates around 60 percent until the mid-eighties, and declines gradually to about 20 percent in the last years of the sample. These numbers are consistent with the 50 percent average share over the entire post-War period computed here.

Compared to Justiniano and Primiceri (2008), this paper abstracts from stochastic volatility, but probes deeper into the sources fluctuations in at least three dimensions. First, it provides a more comprehensive analysis of the contribution of shocks to the variance of the observable variables, focusing in particular on the business cycle frequencies. Second, it investigates in detail why the role of investment shocks was muted in Smets and Wouters (2007). Third, it analyzes the economic mechanisms that turn these disturbances into the key driving forces of business cycles.

The crucial role of investment shocks we uncover is surprising, since these disturbances are unlikely candidates to generate business cycles in neoclassical environments. The reasoning was first outlined by Barro and King (1984). In an efficient equilibrium, the marginal rate of substitution between consumption and leisure-the marginal value of time-equals the marginal product of labor. With standard preferences, this equality implies that consumption and hours move in opposite directions in response to exogenous impulses that do not shift the marginal product, such as the investment shock. Therefore, this shock cannot be a significant 
driving force of business cycles, since their distinguishing feature is the comovement of all real variables.

Our results contradict this conclusion, because the frictions included in the model transform the transmission mechanism of investment shocks with respect to the neoclassical benchmark, contributing to ameliorate the comovement problem. These frictions were first introduced in the literature to bring the impulse responses to monetary shocks in DSGE models closer to those from identified VARs (Christiano, Eichenbaum, and Evans (2005)). They also play a crucial role in turning investment shocks into a viable driving force of fluctuations.

In particular, monopolistic competition with sticky prices and wages is the fundamental mechanism for the transmission of these shocks. This friction breaks the intratemporal efficiency condition described above, by driving an endogenous wedge between the marginal product of labor and the marginal value of time. As a result, the relative movements of consumption and hours are not as tightly constrained as in a perfectly competitive economy.

The rest of the paper is organized as follows. Section 2 outlines our baseline model and section 3 describes the approach to inference and the parameter estimates. Section 4 presents the implications of these estimates for the sources of fluctuations. Section 5 compares our results to those of Smets and Wouters (2007). Section 6 discusses the role of frictions in the transmission of investment shocks, both qualitatively and quantitatively. Section 7 conducts a series of robustness checks. Section 8 concludes. Technical details and additional results on some of the models estimated in the paper are available in the appendix, as well as in an online appendix.

\section{The Model Economy}

This section outlines our baseline model of the U.S. business cycle. It is a medium scale DSGE model with a neoclassical growth core, augmented with several "frictions"-departures from the simplest assumptions on tastes, technology and market structure-now common in the literature.

The economy is populated by five classes of agents. Producers of a final good, which "assemble" a continuum of intermediate goods produced by monopolistic intermediate goods producers. Households, who consume the final good, accumulate capital, and supply differentiated labor services to competitive "employment agencies". A Government. We present their optimization problems in turn. 
2.1. Final goods producers. At every point in time $t$, perfectly competitive firms produce the final consumption good $Y_{t}$ combining a continuum of intermediate goods $\left\{Y_{t}(i)\right\}_{i}, i \in$ $[0,1]$, according to the technology

$$
Y_{t}=\left[\int_{0}^{1} Y_{t}(i)^{\frac{1}{1+\lambda_{p, t}}} d i\right]^{1+\lambda_{p, t}}
$$

The elasticity $\lambda_{p, t}$ follows the exogenous stochastic process

$$
\log \left(1+\lambda_{p, t}\right)=\left(1-\rho_{p}\right) \log \left(1+\lambda_{p}\right)+\rho_{p} \log \left(1+\lambda_{p, t-1}\right)+\varepsilon_{p, t}-\theta_{p} \varepsilon_{p, t-1}
$$

where $\varepsilon_{p, t}$ is i.i.d.N $\left(0, \sigma_{p}^{2}\right)$. The literature refers to this as a price markup shock, since $\lambda_{p, t}$ is the desired markup of price over marginal cost for intermediate firms. As in Smets and Wouters (2007), the ARMA(1,1) structure helps capture the moving average, high frequency component of inflation.

Profit maximization and the zero profit condition imply that the price of the final good, $P_{t}$, is a CES aggregate of the prices of the intermediate goods, $\left\{P_{t}(i)\right\}_{i}$

$$
P_{t}=\left[\int_{0}^{1} P_{t}(i)^{\frac{1}{\lambda_{p, t}}} d i\right]^{\lambda_{p, t}},
$$

and that the demand function for the intermediate good $i$ is

$$
Y_{t}(i)=\left(\frac{P_{t}(i)}{P_{t}}\right)^{-\frac{1+\lambda_{p, t}}{\lambda_{p, t}}} Y_{t} .
$$

2.2. Intermediate goods producers. A monopolist produces the intermediate good $i$ according to the production function

$$
Y_{t}(i)=\max \left\{A_{t}^{1-\alpha} K_{t}(i)^{\alpha} L_{t}(i)^{1-\alpha}-A_{t} F ; 0\right\}
$$

where $K_{t}(i)$ and $L_{t}(i)$ denote the amounts of capital and labor employed by firm $i . F$ is a fixed cost of production, chosen so that profits are zero in steady state (Rotemberg and Woodford (1995), Christiano, Eichenbaum, and Evans (2005)). $A_{t}$ represents exogenous technological progress. Its growth rate $\left(z_{t} \equiv \Delta \log A_{t}\right)$ follows a stationary $\operatorname{AR}(1)$ process

$$
z_{t}=\left(1-\rho_{z}\right) \gamma+\rho_{z} z_{t-1}+\varepsilon_{z, t}
$$

with $\varepsilon_{z, t}$ i.i.d.N $\left(0, \sigma_{z}^{2}\right)$, which implies that the level of technology is non stationary. This is our neutral technology shock. 
As in Calvo (1983), every period a fraction $\xi_{p}$ of intermediate firms cannot choose its price optimally, but reset it according to the indexation rule

$$
P_{t}(i)=P_{t-1}(i) \pi_{t-1}^{\iota_{p}} \pi^{1-\iota_{p}}
$$

where $\pi_{t} \equiv \frac{P_{t}}{P_{t-1}}$ is gross inflation and $\pi$ is its steady state. The remaining fraction of firms choose their price $P_{t}(i)$ optimally, by maximizing the present discounted value of future profits

$$
E_{t}\left\{\sum_{s=0}^{\infty} \xi_{p}^{s} \frac{\beta^{s} \Lambda_{t+s}}{\Lambda_{t}}\left[P_{t}(i)\left(\prod_{k=1}^{s} \pi_{t+k-1}^{\iota_{p}} \pi^{1-\iota_{p}}\right) Y_{t+s}(i)-W_{t+s} L_{t+s}(i)-r_{t+s}^{k} K_{t+s}(i)\right]\right\},
$$

subject to the demand function 2.1 and to cost minimization. In this objective, $\Lambda_{t}$ is the marginal utility of nominal income for the representative household that owns the firm, while $W_{t}$ and $r_{t}^{k}$ are the nominal wage and the rental rate of capital.

2.3. Employment agencies. Firms are owned by a continuum of households, indexed by $j \in[0,1]$. Each household is a monopolistic supplier of specialized labor, $L_{t}(j)$, as in Erceg, Henderson, and Levin (2000). A large number of competitive "employment agencies" combine this specialized labor into a homogenous labor input sold to intermediate firms, according to

$$
L_{t}=\left[\int_{0}^{1} L_{t}(j)^{\frac{1}{1+\lambda_{w, t}}} d j\right]^{1+\lambda_{w, t}} .
$$

As in the case of the final good, the desired markup of wages over the household's marginal rate of substitution, $\lambda_{w, t}$, follows the exogenous stochastic process

$$
\log \left(1+\lambda_{w, t}\right)=\left(1-\rho_{w}\right) \log \left(1+\lambda_{w}\right)+\rho_{w} \log \left(1+\lambda_{w, t-1}\right)+\varepsilon_{w, t}-\theta_{w} \varepsilon_{w, t-1},
$$

with $\varepsilon_{w, t}$ i.i.d.N $\left(0, \sigma_{w}^{2}\right)$. This is the wage markup shock. We also refer to it as a labor supply shock, since it has the same effect on the household's first order condition for the choice of hours as the shock to the preference for leisure popularized by Hall (1997).

Profit maximization by the perfectly competitive employment agencies implies the labor demand function

$$
L_{t}(j)=\left(\frac{W_{t}(j)}{W_{t}}\right)^{-\frac{1+\lambda_{w, t}}{\lambda_{w, t}}} L_{t}
$$

where $W_{t}(j)$ is the wage received from employment agencies by the supplier of labor of type $j$, while the wage paid by intermediate firms for their homogenous labor input is

$$
W_{t}=\left[\int_{0}^{1} W_{t}(j)^{\frac{1}{\lambda_{w, t}}} d j\right]^{\lambda_{w, t}} .
$$


2.4. Households. Each household maximizes the utility function

$$
E_{t}\left\{\sum_{s=0}^{\infty} \beta^{s} b_{t+s}\left[\log \left(C_{t+s}-h C_{t+s-1}\right)-\varphi \frac{L_{t+s}(j)^{1+\nu}}{1+\nu}\right]\right\}
$$

where $C_{t}$ is consumption, $h$ is the degree of habit formation and $b_{t}$ is a shock to the discount factor, which affects both the marginal utility of consumption and the marginal disutility of labor. This intertemporal preference shock follows the stochastic process

$$
\log b_{t}=\rho_{b} \log b_{t-1}+\varepsilon_{b, t},
$$

with $\varepsilon_{b, t} \sim$ i.i.d.N $\left(0, \sigma_{b}^{2}\right)$. Since technological progress is non stationary, utility is logarithimic to ensure the existence of a balanced growth path. Moreover, consumption is not indexed by $j$ because the existence of state contingent securities ensures that in equilibrium consumption and asset holdings are the same for all households.

As a result, the household's flow budget constraint is

$$
P_{t} C_{t}+P_{t} I_{t}+T_{t}+B_{t} \leq R_{t-1} B_{t-1}+Q_{t}(j)+\Pi_{t}+W_{t}(j) L_{t}(j)+r_{t}^{k} u_{t} \bar{K}_{t-1}-P_{t} a\left(u_{t}\right) \bar{K}_{t-1},
$$

where $I_{t}$ is investment, $T_{t}$ are lump-sum taxes, $B_{t}$ is holdings of government bonds, $R_{t}$ is the gross nominal interest rate, $Q_{t}(j)$ is the net cash flow from household's $j$ portfolio of state contingent securities, and $\Pi_{t}$ is the per-capita profit accruing to households from ownership of the firms.

Households own capital and choose the capital utilization rate, $u_{t}$, which transforms physical capital into effective capital according to

$$
K_{t}=u_{t} \bar{K}_{t-1} .
$$

Effective capital is then rented to firms at the rate $r_{t}^{k}$. The cost of capital utilization is $a\left(u_{t}\right)$ per unit of physical capital. In steady state, $u=1, a(1)=0$ and $\chi \equiv \frac{a^{\prime \prime}(1)}{a^{\prime}(1)}$. In the log-linear approximation of the model solution this curvature is the only parameter that matters for the dynamics.

The physical capital accumulation equation is

$$
\bar{K}_{t}=(1-\delta) \bar{K}_{t-1}+\mu_{t}\left(1-S\left(\frac{I_{t}}{I_{t-1}}\right)\right) I_{t}
$$


where $\delta$ is the depreciation rate. The function $S$ captures the presence of adjustment costs in investment, as in Christiano, Eichenbaum, and Evans (2005). In steady state, $S=S^{\prime}=0$ and $S^{\prime \prime}>0 .^{2}$

The investment shock $\mu_{t}$ is a source of exogenous variation in the efficiency with which the final good can be transformed into physical capital, and thus into tomorrow's capital input. Justiniano, Primiceri, and Tambalotti (2009) show that this variation might stem from technological factors specific to the production of investment goods, as in Greenwood, Hercowitz, and Krusell (1997), but also from disturbances to the process by which these investment goods are turned into productive capital. Here, we ignore that distinction and maintain an agnostic stance on the ultimate source of these disturbances.

The investment shock follows the stochastic process

$$
\log \mu_{t}=\rho_{\mu} \log \mu_{t-1}+\varepsilon_{\mu, t}
$$

where $\varepsilon_{\mu, t}$ is i.i.d.N $\left(0, \sigma_{\mu}^{2}\right)$.

As in Erceg, Henderson, and Levin (2000), every period a fraction $\xi_{w}$ of households cannot freely set their wage, but follows the indexation rule

$$
W_{t}(j)=W_{t-1}(j)\left(\pi_{t-1} e^{z_{t-1}}\right)^{\iota_{w}}\left(\pi e^{\gamma}\right)^{1-\iota_{w}}
$$

The remaining fraction of households chooses instead an optimal wage $W_{t}(j)$ by maximizing

$$
E_{t}\left\{\sum_{s=0}^{\infty} \xi_{w}^{s} \beta^{s}\left[-b_{t+s} \varphi \frac{L_{t+s}(j)^{1+\nu}}{1+\nu}+\Lambda_{t+s} W_{t}(j) L_{t+s}(j)\right]\right\},
$$

subject to the labor demand function 2.3.

2.5. The Government. A monetary policy authority sets the nominal interest rate following a feedback rule of the form

$$
\frac{R_{t}}{R}=\left(\frac{R_{t-1}}{R}\right)^{\rho_{R}}\left[\left(\frac{\pi_{t}}{\pi}\right)^{\phi_{\pi}}\left(\frac{X_{t}}{X_{t}^{*}}\right)^{\phi_{X}}\right]^{1-\rho_{R}}\left[\frac{X_{t} / X_{t-1}}{X_{t}^{*} / X_{t-1}^{*}}\right]^{\phi_{d X}} \eta_{m p, t},
$$

where $R$ is the steady state of the gross nominal interest rate. As in Smets and Wouters (2007), interest rates responds to deviations of inflation from its steady state, as well as to the level and the growth rate of the GDP gap $\left(X_{t} / X_{t}^{*}\right){ }^{3}$ The monetary policy rule is also

\footnotetext{
${ }^{2}$ Lucca (2005) shows that this formulation of the adjustment cost function is equivalent (up to first order) to a generalization of the time to build assumption.

3 The GDP gap is the difference between actual GDP $\left(C_{t}+I_{t}+G_{t}\right)$ and its level under flexible prices and wages, and no markup shocks (Woodford (2003)).
} 
perturbed by a monetary policy shock, $\eta_{m p, t}$, which evolves according to

$$
\log \eta_{m p, t}=\rho_{m p} \log \eta_{m p, t-1}+\varepsilon_{m p, t}
$$

where $\varepsilon_{m p, t}$ is i.i.d. $N\left(0, \sigma_{m p}^{2}\right)$.

Fiscal policy is fully Ricardian. The Government finances its budget deficit by issuing short term bonds. Public spending is determined exogenously as a time-varying fraction of output

$$
G_{t}=\left(1-\frac{1}{g_{t}}\right) Y_{t}
$$

where the government spending shock $g_{t}$ follows the stochastic process

$$
\log g_{t}=\left(1-\rho_{g}\right) \log g+\rho_{g} \log g_{t-1}+\varepsilon_{g, t}
$$

with $\varepsilon_{g, t} \sim$ i.i.d.N $\left(0, \sigma_{g}^{2}\right)$.

2.6. Market clearing. The aggregate resource constraint,

$$
C_{t}+I_{t}+G_{t}+a\left(u_{t}\right) \bar{K}_{t-1}=Y_{t}
$$

can be derived by combining the Government's and the households' budget constraints with the zero profit condition of the final goods producers and of the employment agencies.

2.7. Solution. In this model, consumption, investment, capital, real wages and output fluctuate around a stochastic balanced growth path, since the level of technology $A_{t}$ has a unit root. Therefore, the solution involves the following steps. First, rewrite the model in terms of detrended variables. Second, compute the non-stochastic steady state of the transformed model, and log-linearly approximate it around this steady state. The details of these steps can be found in the online appendix. Third, solve the resulting linear system of rational expectation equations to obtain its state space representation. This representation forms the basis for the estimation procedure, which is discussed in the next section.

\section{BAYESIAN INFERENCE}

We use Bayesian methods to characterize the posterior distribution of the structural parameters (see An and Schorfheide (2007) for a survey). The posterior distribution combines the likelihood function with prior information. 
3.1. Data and priors. The likelihood is based on the following vector of observable variables

$$
\left[\Delta \log X_{t}, \Delta \log C_{t}, \Delta \log I_{t}, \log L_{t}, \Delta \log \frac{W_{t}}{P_{t}}, \pi_{t}, \log R_{t}\right],
$$

where $\Delta$ denotes the temporal difference operator. The data is quarterly and spans the period from 1954QIII to 2004QIV. A detailed description of the time series used in the estimation is in appendix A.

The prior information on the structural parameters is summarized in Table $1 .{ }^{4}$ Two parameters are fixed using level information not contained in our dataset: the quarterly depreciation rate of capital $(\delta)$ to 0.025 ; the steady state ratio of government spending to GDP $(1-1 / g)$ to 0.22 , which corresponds to the average value of $G_{t} / X_{t}$ in our sample. The other priors are fairly diffuse and broadly in line with those adopted in previous studies (e.g. Del Negro, Schorfheide, Smets, and Wouters (2007), Levin, Onatski, Williams, and Williams (2005)).

For all but two persistence parameters we use a Beta prior, with mean 0.6 and standard deviation 0.2. One of the two exceptions is neutral technology, which already includes a unit root. For this reason, the prior for the autocorrelation of its growth rate $\left(\rho_{z}\right)$ is centered at 0.4 instead. The prior for the persistence of the monetary policy shocks is also centered at 0.4 , because the policy rule already allows for interest rates inertia.

The intertemporal preference, price and wage markup shocks are normalized to enter with a unit coefficient in the consumption, price inflation and wage equations respectively (see appendix B for details). The priors on the innovations' standard deviations are quite disperse and chosen to generate volatilities for the endogenous variables broadly in line with the data. Their covariance matrix is diagonal.

To evaluate jointly the economic content of the priors on the exogenous processes and the structural parameters, it is useful to look at the implications of these priors for the variance decomposition of the observable variables. This representation of the prior information is more useful than a series of comments on the distributions for specific coefficients, given the focus of the paper on the sources of fluctuations. The view of business cycles built a priori in the estimation is in line with the RBC tradition. In particular, the neutral technology shock accounts on average for $34,38,43$ and 29 percent of the variability of output, consumption, investment and hours respectively. The second most important shock for output and hours

\footnotetext{
${ }^{4}$ In section 7 we show that results change little when estimating the model by maximum likelihood (i.e. with flat priors).
} 
is the government spending shock, which accounts for 31 and 17 percent of their variance (see the online appendix for the full prior variance decomposition). On the contrary, the a priori role of investment shocks for all variables is negligible, with essentially no mass on the variance decomposition that emerges a posteriori. This divergence may be a concern for model comparison, but it also indicates that our results are not driven by the prior.

3.2. Parameter estimates. Table 1 reports the estimates of the model's parameters. The table includes posterior medians, standard deviations and 90 percent probability intervals. These estimates imply a substantial degree of price and wage stickiness, habit formation in consumption and adjustment costs in investment, in line with previous studies (e.g. Altig, Christiano, Eichenbaum, and Linde (2005), Del Negro, Schorfheide, Smets, and Wouters (2007) and Smets and Wouters (2007)). Capital utilization is not very elastic, as also found by Del Negro, Schorfheide, Smets, and Wouters (2007). In response to a 1 percent positive change in the rental rate of capital, utilization increases by slightly less than 0.2 percent.

The estimates of the income share of capital $(\alpha)$ and of the Frisch elasticity of labor supply $(1 / \nu)$ are both lower than the values typically adopted in the RBC literature, although close to those of Smets and Wouters (2007). The main results change little when these parameters are calibrated to more standard values, as shown in section 7 .

\section{Shocks And Business Cycles}

This section analyzes the driving forces of fluctuations by looking at the variance decomposition of the main macroeconomic variables implied by the estimated model.

Table 2 reports the contribution of each shock to the variance of the level of the observable variables at business cycle frequencies, which encompass periodic components with cycles between 6 and 32 quarters, as in Stock and Watson (1999). ${ }^{5}$ The fourth column of the table makes clear that investment shocks account for 50 percent of the fluctuations in output, almost 60 percent of those in hours and more than 80 percent of those in investment, by far the largest shares. On the basis of this evidence, we conclude that investment shocks are the leading source of business cycles.

One qualification to this result comes from consumption. Investment shocks are responsible for only a small fraction of its variability, which is instead largely driven by the otherwise

\footnotetext{
${ }^{5}$ We compute the spectral density of the observable variables implied by the DSGE model and transform it to obtain the spectrum of the level of output, consumption, investment and wages.
} 
irrelevant intertemporal preference shock. This is a symptom of the well-known failure of standard consumption Euler equations to capture the empirical relationship between consumption and interest rates, as argued in Primiceri, Schaumburg, and Tambalotti (2005) (see also Canzoneri, Cumby, and Diba (2007) and Atkeson and Kehoe (2008)).

Figure 1 provides a time series decomposition of the contribution of investment shocks to the variance of output by plotting year-to-year GDP growth in the data (the grey line) and in the model, conditional on the estimated sequence of the investment shocks alone (the black line). The comovement between the two series is striking. In particular, investment shocks appear largely responsible for "dragging" GDP growth down at business cycle troughs. This is especially evident for the last two downturns, as well as for the recessions of the sixties. The main exceptions are the "twin" recessions of the early eighties, in which monetary factors are in fact believed to have played a fundamental role.

Looking at the other shocks and variables in table 2, two results stand out. First, the neutral technology shock remains fairly important. It explains around one quarter of the volatility of output and consumption, and 40 percent of the variance of real wages. This contribution is more limited than usually found in the RBC literature mainly because, in our estimated model, positive productivity shocks have a negative effect on hours (see figure 6 in Justiniano, Primiceri, and Tambalotti (2008)). This fall in hours is consistent with the findings of Smets and Wouters (2007) and of a large empirical literature (Gali (1999), Francis and Ramey (2006), Canova, Lopez-Salido, and Michelacci (2006), Fernald (2007), Basu, Fernald, and Kimball (2007)), although it remains controversial (Christiano, Eichenbaum, and Vigfusson (2004), Uhlig (2003), Chang and Hong (2006)).

The second result to highlight in table 2 is that wage markup shocks explain only 5 and 7 percent of the volatility of output and hours. Interestingly, the contribution of these shocks to fluctuations in hours is much higher (58 percent) if we consider their overall variance, rather than focusing on business cycle frequencies alone. Figure 2 studies the source of this discrepancy by plotting the share of the variance of hours due to the wage markup shock, as a function of the spectrum frequencies. Business cycles correspond to the band within the dotted vertical lines. ${ }^{6}$ The contribution of wage markup shocks is substantial at very low frequencies, but declines steeply towards the business cycle range, where it is mostly below 10 percent.

\footnotetext{
6 The business cycle frequencies are in the band between $2 \pi / 32=0.19$ and $2 \pi / 6=1.05$.
} 
This spectral profile of the contribution of labor supply shocks is consistent with the forecast error variance decomposition for GDP presented by Smets and Wouters (2007), in which the share of variance associated with this shock increases monotonically with the forecast horizon. The advantage of the spectral decomposition in Figure 2 is that it isolates more clearly the contribution of labor supply shocks at business cycle frequencies. ${ }^{7}$ This clarification is important, because medium scale DSGE models à la Smets and Wouters (2007) have been criticized as tools for both monetary policy and business cycle analysis, since they need large labor supply shocks to fit the data (e.g. Chari, Kehoe, and McGrattan (2008), Shimer (2009)). These critiques become less stringent if these shocks are important only to account for low frequency movements in hours, which might be due for example to demographic developments largely unrelated to the business cycle.

In summary, our analysis proposes a parsimonious view of the sources of business cycles. Investment shocks impart the main impetus to fluctuations, which spread from investment to output and hours. Consumption, however, is largely insulated from these disturbances and its comovement with the rest of the economy is mainly driven by neutral technology shocks. Finally, labor supply shocks account for a large fraction of the movements in hours, but these are concentrated at very low frequencies.

As for wages and prices, their movement is mainly driven by exogenous variation in desired markups, as would be expected in an economy in which monetary policy is well calibrated. In this respect, it is especially remarkable that inflation and wages are almost completely insulated from investment shocks. However, the significant contribution of these shocks to the movements in nominal interest rates suggests that achieving this degree of nominal stabilization required a fair amount of activism on the part of monetary policy.

\section{A Comparison with Smets and Wouters (2007)}

The prominent role of investment shocks in our variance decomposition is at odds with some findings in a very influential paper by Smets and Wouters (2007, SW hereafter). SW also study the driving forces of output fluctuations in their DSGE model, but find that their investment shock accounts for less than 25 percent of the forecast error variance in GDP at

\footnotetext{
7 Even Smets and Wouters' (2007) interpretation of the role of labor supply shocks is unclear. They write in the introduction: "While "demand" shocks such as the risk premium, exogenous spending, and investmentspecific technology shocks explain a significant fraction of the short-run forecast variance in output, both wage mark-up (or labor supply) and, to a lesser extent, productivity shocks explain most of its variation in the medium to long run."
} 
any horizon. Our estimates of the contribution of this shock to output are twice as large. This section documents the sources of this discrepancy.

There are several differences between our baseline model and that of SW, both in the details of the theoretical specification and in the measurement of the observable variables. The first two columns of table 3 show that the differences in specification play a negligible role in reconciling the two results. In fact, estimation of our model with SW's dataset attributes only 19 and 22 percent of the business cycle variance of output and hours to investment shocks. These numbers are close to those obtained estimating SW's model with the same dataset (23 and 26 percent), and much lower than the 50 and 59 percent in our baseline estimation. Therefore, the discrepancy in the variance decompositions stems largely from differences in measurement. ${ }^{8}$

Compared to our baseline, SW's dataset excludes (the change in) inventories from investmentalthough not from output - and includes purchases of consumer durables in consumption. ${ }^{9}$ As a result, our investment series is more volatile and procyclical, while consumption is less so. Moreover, the comovement between the two series is less pronounced in our dataset. This is not surprising, since durables and inventories are both volatile and procyclical components of GDP (Stock and Watson (1999)).

Of course, these differences in sample autocovariances translate into changes in parameter estimates. Most strikingly, the inferred investment adjustment cost parameter more than doubles (from 2.85 to 6.47 ) when moving to SW's definition of the observables. This change dampens the impact of investment shocks on investment, but also on output and hours. At the same time, the habit persistence parameter declines (from 0.78 to 0.66 ), making consumption and investment more countercylical in response to investment and intertemporal preference shocks respectively. Moreover, the standard deviation of the latter shock increases substantially (from 0.04 to 0.08 ), while that of the former, perhaps surprisingly, hardly changes (from 6.03 to 6.07$) \cdot{ }^{10}$

\footnotetext{
8 "SW's dataset" uses their definition of the seven observable variables, applied to our sample period, from 1954QIII to 2004QIV.

9 SW also use different series for hours and wages, but this does not have any material impact on the results.

10 Detailed results for our model estimated using SW's dataset are included in the online appendix. These results include posterior parameter estimates and business cycle variance decompositions, as well as a comparison of the impulse responses implied by this estimation with those in the baseline. Also included are the autocovariance structure for output, consumption and investment in the two datasets.
} 
Overall, the parameter estimates obtained with our dataset imply two main changes in the transmission of shocks. First, a more powerful amplification of investment shocks, without exacerbating the countercyclicality of consumption. Second, a weaker response of output and hours to intertemporal preference shocks, but with a more pronounced countercyclical reaction of investment. As a consequence of these changes, we attribute to investment shocks a higher share of the variance of output and hours and a correspondingly lower share to the intertemporal preference shock.

Our definition of investment differs from SW's in two respects: it includes both the change in inventories and expenditures on durable goods. However, the latter difference accounts for about two thirds of the discrepancy between our variance decomposition and SW's. In fact, estimation of our model with durables included in (fixed) investment, rather than in consumption, increases the contribution of investment shocks to business cycle fluctuations from 19 to 42 percent for output and from 22 to 47 percent for hours (third column of table 3 ). The inclusion of inventories accounts for the rest of the gap ( 8 and 12 percentage points for output and hours).

Our treatment of consumer durables as a form of investment is standard in the business cycle literature (see for example Cooley and Prescott (1995), Christiano, Eichenbaum, and Evans (2005), Del Negro, Schorfheide, Smets, and Wouters (2007)). However, this measurement choice requires a stronger argument in its defense, given its consequences for the answer to the central question of the paper. One such argument comes from the estimation of a generalized version of the baseline model, with a more explicit role for durable goods. ${ }^{11}$ In this model, as in Greenwood and Hercowitz (1991) and Chang and Schorfheide (2003), households consume nondurable goods and the service flow of durables. This flow is produced by a home-production technology that combines durables and non-market hours. Households' new purchases of durable goods increase their stock through an accumulation equation that is affected by two shocks: the same investment shock that impinges on the standard capital accumulation and a shock specific to the accumulation of durables. This assumption captures the idea that shocks to the marginal efficiency of firms' investment are correlated with shocks to the efficiency of consumer durables, although not perfectly. This version of the model is estimated with the growth rate of consumer durables as an additional observable variable.

\footnotetext{
11 We thank Frank Schorfheide (the editor) for this suggestion.
} 
A formal description of the model with durables is in appendix $\mathrm{C}$, while details on its estimation and on the implied variance decomposition are available in the online appendix. Here we only report that this model attributes to investment shocks an even larger share of the business cycle volatility of output and hours than our baseline (last column of table 3 ). This result does not change when measuring household investment as the sum of consumer durables and residential investment, as in Greenwood and Hercowitz (1991). We conclude that the treatment of durables as one component of investment, as in our the baseline model, delivers more reliable results on the sources of fluctuations than their inclusion in consumption, as in SW.

\section{Inspecting the Mechanism: How Investment Shocks Become Important}

In standard neoclassical environments, neutral technology shocks are the most natural source of business cycles, since they can easily produce the typical comovement of macroeconomic variables. In fact, Barro and King (1984) show that generating this kind of comovement in response to most other shocks is problematic. In particular, they explicitly identify investment shocks as an unlikely driving force of business cycles. Intuitively, a positive shock to the marginal productivity of investment increases the rate of return, giving households an incentive to save more and postpone consumption. With lower consumption, the marginal utility of income increases, shifting labor supply to the right-an intertemporal substitution effect. Along an unchanged labor demand schedule, this supply shift raises hours and output, but depresses wages and labor productivity.

In our estimated model, on the contrary, investment shocks trigger procyclical movements in all the key macroeconomic variables, as shown in figure $3 .{ }^{12}$ This is due to a significant change in the transmission mechanism, relative to the neoclassical benchmark, that allows investment shocks to emerge as the single most important source of business cycle fluctuations. This section considers more closely how the frictions included in the baseline model contribute to this result. Some of these frictions, such as endogenous capital utilization and investment adjustment costs, have been analyzed before in a similar context, most prominently by Greenwood, Hercowitz, and Huffman (1988) and Greenwood, Hercowitz, and

\footnotetext{
12 Consumption is flat initially and increases with a delay of about one year. This response explains why investment shocks account for a small fraction of the movements in consumption. Eusepi and Preston (2009), Furlanetto and Seneca (2009), Guerrieri, Henderson, and Kim (2009) and Khan and Tsoukalas (2009) explore several mechanisms that enhance the procyclicality of consumption in response to investment shocks.
} 
Krusell (2000). Others, such as monopolistic competition with sticky prices and wages, have not. $^{13}$

To organize this discussion, start from the efficiency equilibrium condition that must hold in a neoclassical economy:

$$
\operatorname{MRS}\left(\begin{array}{c}
C \\
+
\end{array},+\underset{+}{L}\right)=\operatorname{MPL}(\underset{-}{L})
$$

With standard preferences and technology, the marginal rate of substitution $(M R S)$ depends positively on consumption $(C)$ and hours $(L)$, while the marginal product of labor $(M P L)$ is decreasing in hours. As a result, any shock that boosts hours on impact, without shifting the marginal product of labor schedule, must also generate a fall in consumption for 6.1 to hold at the new equilibrium. This is precisely what happens in response to investment shocks in a neoclassical model, as was discussed above.

Equation 6.1 also highlights the three margins on which the frictions included in our baseline model must be operating to make the transmission of investment shocks more conformable with the typical pattern of business cycles. Departures from the standard assumptions on tastes affect the form of the $M R S$, technological frictions affect the form of the $M P L$, while departures from perfect competition create a wedge between the two.

For instance, with internal habit formation, the $M R S$ also becomes a function of past and future expected consumption. Intuitively, households become reluctant to sharply adjust their consumption, which reduces their willingness to substitute over time. As a consequence, consumption is less likely to fall significantly in response to a positive investment shock.

Endogenous capital utilization, instead, acts as a shifter of the $M P L$, as first highlighted by Greenwood, Hercowitz, and Huffman (1988). By increasing the utilization of existing capital, investment shocks increase the marginal product of labor on impact, shifting labor demand. Along a fixed labor supply schedule, this shift implies a rise in hours and wages, as well as in consumption.

Finally, monopolistic competition in goods and labor markets drives a wedge between the $M R S$ and the $M P L$. Sticky prices and wages make this wedge endogenous, so that equation

\footnotetext{
13 Rotemberg and Woodford (1995) point out that endogenous markup variation is an additional channel through which aggregate shocks might affect fluctuations, especially in employment. However, they do not consider investment shocks in their analysis.
} 
6.1 becomes

$$
\omega\left({ }_{-}^{L}\right) \operatorname{MRS}\left(\begin{array}{c}
C_{+}, L_{+} \\
-
\end{array}\right)=\operatorname{MPL}\left(\underline{L}_{-}^{L}\right)
$$

where $\omega$ denotes the wedge. In our model, $\omega$ is the sum of two equilibrium markups, that of price over marginal cost and that of real wages over the marginal rate of substitution. If this markup is countercyclical (i.e. it falls when hours rise, as suggested for example by Rotemberg and Woodford (1999) and Gali, Gertler, and Lopez-Salido (2007)), consumption and hours can move together in response to an investment shock, without violating the equilibrium condition 6.2 .

More specifically, in our estimated model, a positive investment shock produces a drop in the price markup, as evident from the fact that the real marginal cost rises in figure 3 . This fall in the markup induces a positive shift in labor demand, which amplifies the shift associated with changes in utilization. At the same time, the wage markup also falls, shifting the labor supply schedule to the right. Unlike in the perfectly competitive case, though, this shift in labor supply is consistent with an increase in hours at an unchanged level of consumption.

In our economy, the endogeneity of markups is due to price and wage stickiness. However, equation (6.2) suggests that any other friction resulting in countercyclical markups would propagate investment shocks in a similar way.

The rest of this section investigates the quantitative role of all these frictions in turning investment shocks into the dominant source of fluctuations. For this purpose, we re-estimate several restricted versions of the baseline model, shutting down one category of frictions at-a-time, and study the resulting variance decomposition. The restricted models under consideration are the following. First, a model with no habit in consumption, which corresponds to $h=0$. Second, a model with no capital utilization margin and investment adjustment costs, obtained by setting $1 / \chi=0.001$ and $S^{\prime \prime}=0$. Third and fourth, models with (nearly) competitive labor and goods markets, in which $\xi_{w}=0.01, \iota_{w}=0, \lambda_{w}=1.01$ and $\xi_{p}=0.01$, $\iota_{p}=0, \lambda_{p}=1.01$ respectively. Finally, a model with no frictions, which corresponds to the neoclassical core embedded in the baseline specification.

The results of this exercise are reported in table 4 . The table focuses on the contributions of investment shocks to the volatility of output and hours at business cycle frequencies. The first result to note is that removing any of the frictions reduces the contribution of 
investment shocks to fluctuations. This is as expected, given the preceding discussion of how these frictions alter the transmission mechanism.

In terms of relative contributions, imperfect competition has the most significant marginal impact. In the perfectly competitive model, the contribution of investment shocks to fluctuations in output and hours drops to 4 and 8 percent respectively. Shutting down imperfect competition in goods and labor markets separately produces a roughly equal decline in the importance of investment shocks. Endogenous utilization and adjustment costs come next. Their exclusion reduces the contribution of investment shocks to fluctuations in both hours and output by more than half, compared with the baseline. The friction that plays the smallest role at the margin is time non-separability.

Finally, the last column in table 4 shows that the contribution of the investment shock disappears entirely in the frictionless model. This result suggests that the estimation procedure is not affecting our findings on the role of this shock in business cycles. In the estimated version of the neoclassical model obtained by restricting the baseline specification, investment shocks do not play any role in fluctuations, as it should be expected in light of the theoretical analysis of Barro and King (1984) and Greenwood, Hercowitz, and Huffman (1988). ${ }^{14}$

The models in table 4 encompass a wide range of views on the sources of business cycles. In this paper, we proposed investment shocks as the key driving force. Other researchers might look at table 4 and conclude otherwise if, for instance, they prefer the neoclassical growth model to our baseline. However, one compelling reason to prefer the latter is that its fit is far superior to that of any of the alternatives considered here, as shown by the marginal data densities (or marginal likelihoods) reported in the last row of table 4. The marginal likelihood of the baseline model is more than 100 log-points higher than that of the next best model, implying overwhelming posterior odds in its favor. ${ }^{15}$

\section{Robustness Analysis}

This section investigates the robustness of our main finding to a number of alternative specifications of the model. The results of these robustness checks are summarized in table

\footnotetext{
${ }^{14}$ In the estimated frictionless model, the neutral technology and labor supply shocks explain 43 and 45 percent of the variance of output and 4 and 77 percent of that of hours at business cycle frequencies.

15 Del Negro and Schorfheide (2008) discuss reasons why posterior odds should be interpreted with some care when priors are not adjusted as the model specification is altered.
} 
5 , which reports the share of the variance of output and hours explained by the investment shock at business cycle frequencies for the baseline and several alternative specifications.

\subsection{Standard calibration of capital income share and labor supply elasticity $(\alpha=$}

0.3 and $\nu=1)$. The baseline estimates of the share of capital income $(\alpha)$ and of the Frisch elasticity of labor supply $(1 / \nu)$ are different from the typical values used in the RBC literature. However, the second column of table 5 shows that the contribution of investment shocks to the business cycle fluctuations of output and hours increases with respect to the baseline, if these two parameters are calibrated to the more typical values of $\alpha=0.3$ and $\nu=1$.

7.2. No ARMA shocks. Following Smets and Wouters (2007), the baseline model includes an $\operatorname{ARMA}(1,1)$ specification for the wage and price markup shocks. Results are very similar when markup shocks are assumed to follow an $\mathrm{AR}(1)$ process instead, as illustrated in column three of table 5 .

7.3. GDP growth in the policy rule. We also experimented with a model in which the interest rate responds to output growth, rather than to the output gap, since both specifications are common in the literature. In this case, the contribution of investments shocks falls slightly with respect to the baseline case, as shown in column four of table 5 .

7.4. Maximum likelihood. The last robustness check is with respect to the priors on the model parameters. The baseline exercise uses the prior information reported in table 1, following the recent literature on Bayesian estimation of DSGE models. One objection to this methodology is that the results might be unduly influenced by this information, although the role of investment shocks is negligible in the prior variance decomposition described in section 3.1. As a further check, we also estimated the model by maximum likelihood. Maximizing the likelihood is numerically much more challenging than maximizing the posterior, since the use of weakly informative priors ameliorates the problems caused by flat areas in the likelihood surface and by multiple local modes. These difficulties notwithstanding, we were able to compute maximum likelihood estimates for the model parameters. ${ }^{16}$ The implications of these estimates for the variance decomposition are illustrated in the last column of table 5 ,

\footnotetext{
16 More precisely, to maximize the likelihood we need to calibrate $\varkappa$, since the likelihood is not very informative on this parameter and this creates convergence problems in the maximization routine. Therefore, we calibrated $\varkappa=5$, which is our prior mean. This value of $\varkappa$ implies a low elasticity of capital utilization, which makes the propagation of investment shocks if anything more problematic.
} 
which makes clear that investment shocks still account for around 60 percent of the business cycle fluctuations in output and hours.

\section{Concluding Remarks}

What is the source of business cycle fluctuations? We revisited this fundamental question of macroeconomics from the perspective of an estimated New Neoclassical Synthesis model. The main finding is that investment shocks - shocks to the marginal efficiency of investmentare the main drivers of movements in hours, output and investment over the cycle. Imperfect competition with endogenous markups is crucial for the transmission of these shocks. Neutral technology shocks also retain a non negligible role in the fluctuations of consumption and output and are mainly responsible for their comovement. Shocks to labor supply account for a large share of the variance of hours at very low frequencies, but their contribution over the business cycle is negligible.

One qualification to these results is that the estimated volatility of our investment shock is larger than that of the price of investment relative to consumption measured in the data. In a simple two-sector representation of our model, in which the sector producing investment goods is perfectly competitive, the two would be the same. As we argue in Justiniano, Primiceri, and Tambalotti (2009), however, there are important sources of variation in the marginal efficiency of investment that are not captured by changes in the relative price. One example are frictions in the capital accumulation process, perhaps related to the intermediation ability of the financial sector. Models that explicitly include these type of frictions, such as that in Christiano, Motto, and Rostagno (2007), therefore represent a promising avenue for future research.

\section{Appendix A. The Data}

Our dataset spans the period from 1954QIII to 2004QIV. All data are extracted from the Haver Analytics database (series mnemonics in parenthesis). Following Del Negro, Schorfheide, Smets, and Wouters (2007), real GDP is constructed by diving the nominal series (GDP) by population (LF and LH) and the GDP Deflator (JGDP). Real series for consumption and investment are obtained in the same manner, although consumption corresponds only to personal consumption expenditures on non-durables (CN) and services (CS), while investment is the sum of personal consumption expenditures on durables (CD) and 
gross private domestic investment (I). Real wages correspond to nominal compensation per hour in the non-farm business sector (LXNFC), divided by the GDP deflator. The labor input is measured by the log of hours of all persons in the non-farm business sector (HNFBN), divided by population. The quarterly log difference in the GDP deflator and the effective Federal Funds rate are our measures of inflation and the nominal interest rate. No series is demeaned or detrended.

\section{Appendix B. Normalization of the Shocks}

As in Smets and Wouters (2007), some of the exogenous shocks are re-normalized by a constant term. In particular, we normalize the price and wage markups shocks and the intertemporal preference shock, but not the investment shock.

More specifically, the log-linearized Phillips curve is

$$
\hat{\pi}_{t}=\frac{\beta}{1+\beta \iota_{p}} E_{t} \hat{\pi}_{t+1}+\frac{1}{1+\beta \iota_{p}} \hat{\pi}_{t-1}+\kappa \hat{s}_{t}+\kappa \hat{\lambda}_{p, t} .
$$

The normalization consists of defining a new exogenous variable, $\hat{\lambda}_{p, t}^{*} \equiv \kappa \hat{\lambda}_{p, t}$, and estimating the standard deviation of the innovation to $\hat{\lambda}_{p, t}^{*}$ instead of $\hat{\lambda}_{p, t}$. We do the same for the wage markup and the intertemporal preference shock, for which the normalizations are

$$
\begin{aligned}
\hat{\lambda}_{w, t}^{*} & =\left(\frac{\left(1-\beta \xi_{w}\right)\left(1-\xi_{w}\right)}{\left(1+\nu\left(1+\frac{1}{\lambda_{w}}\right)\right)(1+\beta) \xi_{w}}\right) \hat{\lambda}_{w, t} \\
\hat{b}_{t}^{*} & =\left(\frac{\left(1-\rho_{b}\right)\left(e^{\gamma}-h \beta \rho_{b}\right)\left(e^{\gamma}-h\right)}{e^{\gamma} h+e^{2 \gamma}+\beta h^{2}}\right) \hat{b}_{t} .
\end{aligned}
$$

These normalizations are chosen so that these shocks enter their equations with a coefficient of one. In this way, it is easier to choose a reasonable prior for their standard deviation. Moreover, the normalization is a practical way to impose correlated priors across coefficients, which is desirable in some cases. For instance, imposing a prior on the standard deviation of the innovation to $\hat{\lambda}_{p, t}^{*}$ corresponds to imposing priors that allow for correlation between $\kappa$ and the standard deviation of the innovations to $\hat{\lambda}_{p, t}$. Often, these normalizations improve the convergence properties of the MCMC algorithm.

\section{Appendix C. A Model with Durable Goods}

Section 5 presents the results of a variance decomposition exercise based on a model with an explicit role for durable goods in home production. This appendix describes it in some detail. 
The optimization problems of the final and intermediate good producers, the employment agencies and the behavior of the government are identical to those in the baseline model of section 2. The household problem is instead somewhat more involved.

Each household maximizes the utility function

$$
E_{t} \sum_{s=0}^{\infty} \beta^{s} b_{t+s}\left[\log \left(C_{t+s}-h C_{t+s-1}\right)-\varphi \frac{\left(L_{t+s}+L_{h, t+s}\right)^{1+\nu}}{1+\nu}\right],
$$

where $L_{t}$ now denotes market hours and $L_{h, t}$ is the amount of hours spent in home production. Unlike in the baseline specification, we follow SW and assume that households' labor is homogenous and gets differentiated by labor unions with market power. These unions purchase labor from the households at wage $W_{t}^{h}$ and sell it to the employment agencies as a differentiated product at wage $W_{t}(j)$ for labor of type $j$.

$C_{t}$ is now a constant elasticity of substitution (CES) aggregate of consumption of nondurable goods and services $\left(N_{t}\right)$ and of the service flow from durable goods $\left(S_{t}\right)$

$$
C_{t}=\left[\theta N_{t}^{\frac{\eta-1}{\eta}}+(1-\theta) S_{t}^{\frac{\eta-1}{\eta}}\right]^{\frac{\eta}{\eta-1}}
$$

where $\eta$ is the elasticity of substitution between the two components. The service flow from durables is itself a CES aggregate of the stock of durable goods available to the household and the time spent in the home-production process:

$$
S_{t}=\left[\psi\left(A_{t} L_{h, t}\right)^{\frac{\tau-1}{\tau}}+(1-\psi) D_{t}^{\frac{\tau-1}{\tau}}\right]^{\frac{\tau}{\tau-1}},
$$

where $D_{t}$ is the stock of durable goods and we are assuming that neutral technology also affects the efficiency of home production. This specification encompasses cases in which time and durables are complements or substitutes. If $\tau=1$, the home technology reduces to a Cobb-Douglas production function. If $\psi=0$, the service flow from durable goods is simply a constant share of the stock of durables.

With this generalization, the household's budget constraint becomes

$$
P_{t} N_{t}+P_{t} I_{d, t}+P_{t} I_{t}+T_{t}+B_{t} \leq R_{t-1} B_{t-1}+Q_{t}+\Pi_{t}+W_{t}^{h} L_{t}+r_{t}^{k} u_{t} \bar{K}_{t-1}-P_{t} a\left(u_{t}\right) \bar{K}_{t-1} .
$$

$I_{d, t}$ denotes purchases of durable goods, whose stock evolves according to

$$
D_{t+1}=(1-\delta) D_{t}+\mu_{t} \zeta_{t}\left(1-S\left(\frac{I_{d, t}}{I_{d, t-1}}\right)\right) I_{d, t}
$$


Note that the accumulation of durable goods is affected by two shocks: the same investment shock that impinges on the standard capital accumulation, $\mu_{t}$, and a shock specific to the accumulation of durables, which evolves as

$$
\log \zeta_{t}=\rho_{\zeta} \log \zeta_{t-1}+\varepsilon_{\zeta, t}
$$

where $\varepsilon_{\zeta, t}$ is i.i.d.N $\left(0, \sigma_{\zeta}^{2}\right)$.

This model involves six additional parameters with respect to the baseline, which correspond to the coefficients of the CES aggregators $(\theta, \eta, \psi$ and $\tau)$ and the autocorrelation and innovation variance parameters $\rho_{\zeta}$ and $\sigma_{\zeta}$. We derive the mapping between $[\theta, \psi]$ and $\left[\frac{L_{h}}{L}, \frac{I_{d}}{I}\right]$, and estimate the latter instead of the former. Our prior for the two elasticities of substitution $(\eta$ and $\tau$ ) is centered on the Cobb-Douglas case, using a Gamma density with mean equal to 1 and standard deviation equal to 0.2. In line with Chang and Schorfheide (2003), we adopt a Gamma prior for the two steady-state ratios $\left(\frac{L_{h}}{L}\right.$ and $\left.\frac{I_{d}}{I}\right)$ with mean 0.7 and standard deviation 0.1. The prior for $\rho_{\zeta}$ is a Beta with mean 0.4 and standard deviation 0.2 , while the prior for $\sigma_{\zeta}$ is an Inverse-Gamma centered with mean 0.25 and standard deviation 1. The priors on the remaining coefficients are identical to those of the baseline model.

We estimate this version of the model with the growth rate of consumer durables as an additional observable variable. As we show in the online appendix, the posterior modes of $\frac{L_{h}}{L}$ and $\frac{I_{d}}{I}$ are 0.47 and 0.72 respectively. The former is broadly consistent with the estimates of Chang and Schorfheide (2003), while the latter is in line with the average ratio of durable to investment goods in the data. The posterior modes of $\eta$ and $\tau$ are 0.58 and 0.61 respectively. These estimates imply that nondurable consumption and the service flow from durables, as well as durable goods and time, are complements. This result is at odds with the estimates of Chang and Schorfheide (2003), but is consistent with the findings of Greenwood and Hercowitz (1991), who stress the importance of technological complementarity in home production for the allocation of capital and time across sectors.

\section{REFERENCES}

Altig, D., L. J. Christiano, M. Eichenbaum, And J. Linde (2005): "Firm-Specific Capital, Nominal Rigidities and the Business Cycle," NBER Working Paper No. 11034.

An, S., And F. Schorfheide (2007): "Bayesian Analysis of DSGE Models," Econometric Reviews, 24(2-4), 113-172, forthcoming. 
Atkeson, A., And P. J. Kehoe (2008): "On the Need for a New Approach to Analyzing Monetary Policy," NBER Working Papers 14260, National Bureau of Economic Research, Inc.

Barro, R. J., AND R. G. King (1984): "Time-Separable Preference and Intertemporal-Substitution Models of Business Cycles," Quarterly Journal of Economics, 99(4), 817-839.

Basu, S., J. Fernald, And M. Kimball (2007): "Are Technology Improvements Contractionary?," American Economic Review, Forthcoming.

Beaudry, P., And F. Portier (2006): "Stock Prices, News, and Economic Fluctuations," American Economic Review, 96(4), 1293-1307.

Calvo, G. (1983): "Staggered Prices in a Utility-Maximizing Framework," Journal of Monetary Economics, $12(3), 383-98$.

Canova, F., D. Lopez-Salido, And C. Michelacci (2006): "On the Robust Effects of Technology Shocks on Hours Worked and Output," mimeo, Universitat Pompeu Fabra.

Canzoneri, M. B., R. E. Cumby, And B. T. Diba (2007): "Euler equations and money market interest rates: A challenge for monetary policy models," Journal of Monetary Economics, 54(7), 1863-1881.

Chang, Y., And J. H. Hong (2006): "Do Technological Improvements in the Manufacturing Sector Raise or Lower Employment?," American Economic Review, 96(1), 352-368.

Chang, Y., AND F. Schorfheide (2003): "Labor-supply shifts and economic fluctuations," Journal of Monetary Economics, 50(8), 1751-1768.

Chari, V., P. J. Kehoe, And E. R. McGrattan (2008): "New Keynesian Models Are Not Yet Useful for Policy Analysis," Federal Reserve Bank of Minneapolis Working Paper 664.

Christiano, L. J., M. Eichenbaum, And C. L. Evans (2005): "Nominal Rigidities and the Dynamic Effect of a Shock to Monetary Policy," The Journal of Political Economy, 113(1), 1-45.

Christiano, L. J., M. Eichenbaum, And R. Vigfusson (2004): "What Happens After a Technology Shock?," mimeo, Northwestern University.

Christiano, L. J., R. Motto, And M. Rostagno (2007): "Financial Factors in Business Cycles," mimeo, Northwestern University.

Cochrane, J. H. (1994): "Shocks," Carnegie-Rochester Conference Series on Public Policy, 41, $295-364$.

Cooley, T. F., And E. Prescott (1995): "Economic Growth and Business Cycles," in Frontiers of Business Cycle Research, ed. by T. F. Cooley, chap. 1, pp. 1-38. Princeton University Press, Princeton, NJ.

Del Negro, M., And F. Schorfheide (2008): "Forming Priors for DSGE Models (And How It Affects the Assessment of Nominal Rigidities)," mimeo, Federal Reserve Bank of New York.

Del Negro, M., F. Schorfheide, F. Smets, And R. Wouters (2007): "On the Fit and Forecasting Performance of New Keynesian Models," Journal of Business and Economic Statistics, 25(2), 123-162, Forthcoming.

Erceg, C. J., D. W. Henderson, And A. T. Levin (2000): "Optimal Monetary Policy with Staggered Wage and Price Contracts," Journal of Monetary Economics, 46(2), 281-313.

Eusepi, S., And B. Preston (2009): "Labor Supply Heterogeneity and Macroeconomic Co-Movement," mimeo, Federal Reserve Bank of New York. 
Fernald, J. (2007): "Trend Breaks, Long-Run Restrictions, and Contractionary Technology Improvements,"

Federal Reserve bank of San Francisco Working Paper Series, No. 2005-21.

Fisher, J. D. M. (2006): "The Dynamic Effect of Neutral and Investment-Specific Technology Shocks," Journal of Political Economy, 114(3), 413-451.

Francis, N. R., AND V. A. Ramey (2006): "Measures of Hours Per Capita and their Implications for the Technology-Hours Debate," University of California, San Diego, mimeo.

Furlanetto, F., And M. Seneca (2009): "Investment-Specific Technology Shocks and Consumption," mimeo, Norges Bank.

GaLI, J. (1999): "Technology, Employment, and the Business Cycle: Do Technology Shocks Explain Aggregate Fluctuations?," American Economic Review, 89(1), 249-271.

Gali, J., M. Gertler, And D. Lopez-Salido (2007): "Markups, Gaps and the Welfare Costs of Business Fluctuations," Review of Economics and Statistics, 89(1), 44-59.

Goodfriend, M., And R. G. King (1997): "The New Neoclassical Synthesis and the Role of Monetary Policy," NBER Macroeconomics Annual, 12, 231-283.

Greenwood, J., And Z. Hercowitz (1991): "The Allocation of Capital and Time over the Business Cycle," Journal of Political Economy, 99(6), 1188-214.

Greenwood, J., Z. Hercowitz, And G. W. Huffman (1988): "Investment, Capacity Utilization, and the Real Business Cycle," American Economic Review, 78(3), 402-417.

Greenwood, J., Z. Hercowitz, And P. Krusell (1997): "Long Run Implications of Investment-Specific Technological Change," American Economic Review, 87(3), 342-362.

(2000): "The role of investment-specific technological change in the business cycle," European Economic Review, 44(1), 91-115.

Guerrieri, L., D. Henderson, And J. Kim (2009): "Interpreting Investment-Specific Technology Shocks," mimeo, Federal Reserve Board.

HALl, R. E. (1997): "Macroeconomic Fluctuations and the Allocation of Time," Journal of Labor Economics, $15(2), 223-250$.

Jaimovich, N., And S. Rebelo (2009): "Can News About the Future Drive the Business Cycle?," American Economic Review, forthcoming.

Justiniano, A., And G. E. Primiceri (2008): "The Time Varying Volatility of Macroeconomic Fluctuations," American Economic Review, 98(3), 604-41.

Justiniano, A., G. E. Primiceri, And A. Tambalotti (2008): "Investment Shocks and Business Cycles," CEPR Discussion Papers 6739, C.E.P.R. Discussion Papers.

Justiniano, A., G. E. Primiceri, And A. Tambalotti (2009): "Investment Shocks and the Relative Price of Investment," mimeo, Northwestern University.

Khan, H., And J. Tsoukalas (2009): "Investment Shocks and the Comovement Problem," mimeo, Carleton University.

King, R. G., C. I. Plosser, J. H. Stock, And M. W. Watson (1991): "Stochastic Trends and Economic Fluctuations," American Economic Review, 81(4), 819-840. 
King, R. G., And S. T. Rebelo (1999): "Resuscitating Real Business Cycles," in Handbook of Macroeconomics, ed. by J. B. Taylor, and M. Woodford, Amsterdam. North-Holland.

Kydland, F. E., And E. C. Prescott (1982): "Time to Build and Aggregate Fluctuations," Econometrica, $50(6), 1345-70$.

Levin, A. T., A. Onatski, J. C. Williams, And N. Williams (2005): "Monetary Policy Under Uncertainty in Micro-Founded Macroeconometric Models," in NBER Macroeconomics Annual.

LuccA, D. O. (2005): "Resuscitating Time to Build," mimeo, Board of Governors of the Federal Reserve System.

Primiceri, G. E., E. Schaumburg, And A. Tambalotti (2005): "Intertemporal Disturbances," mimeo, Northwestern University.

Rotemberg, J. J., And M. Woodford (1995): "Dynamic General Equilibrium Models with Imperfectly Competitive Product Markets," in Frontiers of Business Cycle Research, ed. by T. F. Cooley, chap. 9, pp. 243-293. Princeton University Press, Princeton, NJ.

(1999): "The Cyclical Behavior of Prices and Costs," in Handbook of Macroeconomics, ed. by J. B. Taylor, and M. Woodford, chap. 16, pp. 1051-1135. Elsevier.

Shapiro, M. D., And M. Watson (1988): "Sources of Business Cycle Fluctuations," in NBER Macroeconomics Annual, pp. 111-148. MIT Press, Cambridge, Massachusetts.

Shimer, R. (2009): "Convergence in Macroeconomics: The Labor Wedge," American Economic Journal: Macroeconomics, 1(1), 280-97.

Sims, C. A. (1980): "Macroeconomics and Reality," Econometrica, 48(1), 1-48.

Smets, F., AND R. Wouters (2007): "Shocks and Frictions in US Business Cycles: A Bayesian Approach," American Economic Review, 97(3), 586-606, forthcoming.

Stock, J. H., And M. W. Watson (1999): Business Cycle Fluctuations in US Macroeconomic Time Serieschap. 1, pp. 3-64. Elsevier.

Uhlig, H. (2003): "Do Technology Shocks Lead to a Fall in Total Hours Worked?," mimeo, University of Chicago.

Woodford, M. (2003): Interest and Prices: Foundations of a Theory of Monetary Policy. Princeton University Press, Princeton, NJ.

Federal Reserve Bank of Chicago

E-mail address: ajustiniano@frbchi.org

Northwestern University, CEPR And NBER

E-mail address: g-primiceri@northwestern.edu

Federal Reserve Bank of New York

E-mail address: andrea.tambalotti@ny.frb.org 
Table 1: Prior densities and posterior estimates for the baseline model

\begin{tabular}{|c|c|c|c|c|c|c|c|c|c|c|c|}
\hline \multirow[b]{2}{*}{ Coefficient } & \multirow[b]{2}{*}{ Description } & \multicolumn{3}{|c|}{ Prior } & \multicolumn{7}{|c|}{ Posterior $^{2}$} \\
\hline & & $\begin{array}{c}\text { Prior } \\
\text { Density }^{1} \\
\end{array}$ & Mean & Std & Median & Std & {[} & 5 & & 95 & ] \\
\hline$\alpha$ & Capital share & $\mathrm{N}$ & 0.30 & 0.05 & 0.17 & 0.01 & {[} & 0.16 & , & 0.18 & ] \\
\hline$l_{p}$ & Price indexation & B & 0.50 & 0.15 & 0.24 & 0.08 & {[} & 0.12 & , & 0.38 & ] \\
\hline$l_{w}$ & Wage indexation & B & 0.50 & 0.15 & 0.11 & 0.03 & {[} & 0.06 & , & 0.16 & ] \\
\hline $100 \gamma$ & SS technology growth rate & $\mathrm{N}$ & 0.50 & 0.03 & 0.48 & 0.02 & {[} & 0.44 & , & 0.52 & ] \\
\hline$h$ & Consumption habit & B & 0.50 & 0.10 & 0.78 & 0.04 & {[} & 0.72 & , & 0.84 & ] \\
\hline$\lambda_{p}$ & SS price markup & $\mathrm{N}$ & 0.15 & 0.05 & 0.23 & 0.04 & {[} & 0.17 & , & 0.29 & ] \\
\hline$\lambda_{w}$ & SS wage markup & $\mathrm{N}$ & 0.15 & 0.05 & 0.15 & 0.04 & {[} & 0.08 & , & 0.22 & ] \\
\hline $\log L^{s s}$ & SS log-hours & $\mathrm{N}$ & 0.00 & 0.50 & 0.38 & 0.47 & {[} & -0.39 & , & 1.15 & ] \\
\hline $100(\pi-1)$ & SS quarterly inflation & $\mathrm{N}$ & 0.50 & 0.10 & 0.71 & 0.07 & {[} & 0.58 & , & 0.82 & ] \\
\hline $100\left(\beta^{-1}-1\right)$ & Discount factor & G & 0.25 & 0.10 & 0.13 & 0.04 & {[} & 0.07 & & 0.21 & ] \\
\hline$v$ & Inverse Frisch elasticity & G & 2.00 & 0.75 & 3.79 & 0.76 & {[} & 2.70 & , & 5.19 & ] \\
\hline$\xi_{p}$ & Calvo prices & B & 0.66 & 0.10 & 0.84 & 0.02 & {[} & 0.80 & , & 0.87 & ] \\
\hline$\xi_{w}$ & Calvo wages & B & 0.66 & 0.10 & 0.70 & 0.05 & {[} & 0.60 & , & 0.78 & ] \\
\hline$\chi$ & $\begin{array}{l}\text { Elasticity capital } \\
\text { utilization costs }\end{array}$ & G & 5.00 & 1.00 & 5.30 & 1.01 & {[} & 3.84 & , & 7.13 & ] \\
\hline$S^{\prime \prime}$ & $\begin{array}{l}\text { Investment adjustment } \\
\text { costs }\end{array}$ & G & 4.00 & 1.00 & 2.85 & 0.54 & {[} & 2.09 & , & 3.88 & ] \\
\hline$\phi_{\pi}$ & Taylor rule inflation & $\mathrm{N}$ & 1.70 & 0.30 & 2.09 & 0.17 & {[} & 1.84 & , & 2.39 & ] \\
\hline$\phi_{X}$ & Taylor rule output & $\mathrm{N}$ & 0.13 & 0.05 & 0.07 & 0.02 & {[} & 0.04 & , & 0.10 & ] \\
\hline$\phi_{d X}$ & Taylor rule output growth & $\mathrm{N}$ & 0.13 & 0.05 & 0.24 & 0.02 & {[} & 0.20 & , & 0.28 & ] \\
\hline$\rho_{R}$ & Taylor rule smoothing & B & 0.60 & 0.20 & 0.82 & 0.02 & {[} & 0.79 & , & 0.86 & ] \\
\hline
\end{tabular}

(Continued on the next page) 
Table 1: Prior densities and posterior estimates for the baseline model

\begin{tabular}{|c|c|c|c|c|c|c|c|c|c|c|c|}
\hline \multirow[b]{2}{*}{ Coefficient } & \multirow[b]{2}{*}{ Description } & \multicolumn{3}{|c|}{ Prior } & \multicolumn{7}{|c|}{ Posterior $^{2}$} \\
\hline & & $\begin{array}{c}\text { Prior } \\
\text { Density }{ }^{1}\end{array}$ & Mean & Std & Median & Std & {[} & 5 & & 95 & ] \\
\hline$\rho_{m p}$ & Monetary policy & B & 0.40 & 0.20 & 0.14 & 0.06 & {[} & 0.05 & , & 0.25 & ] \\
\hline$\rho_{z}$ & Neutral technology growth & B & 0.40 & 0.20 & 0.23 & 0.06 & {[} & 0.14 & , & 0.32 & ] \\
\hline$\rho_{g}$ & Government spending & B & 0.60 & 0.20 & 0.99 & 0.00 & {[} & 0.99 & 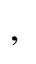 & 0.99 & ] \\
\hline$\rho_{\mu}$ & Investment & B & 0.60 & 0.20 & 0.72 & 0.04 & {[} & 0.65 & 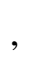 & 0.79 & ] \\
\hline$\rho_{p}$ & Price markup & B & 0.60 & 0.20 & 0.94 & 0.02 & {[} & 0.90 & , & 0.97 & ] \\
\hline$\rho_{w}$ & Wage markup & B & 0.60 & 0.20 & 0.97 & 0.01 & {[} & 0.95 & , & 0.99 & ] \\
\hline$\rho_{b}$ & Intertemporal preference & B & 0.60 & 0.20 & 0.67 & 0.04 & {[} & 0.60 & , & 0.73 & ] \\
\hline$\theta_{p}$ & Price markup MA & B & 0.50 & 0.20 & 0.77 & 0.07 & {[} & 0.61 & , & 0.85 & ] \\
\hline$\theta_{w}$ & Wage markup MA & B & 0.50 & 0.20 & 0.91 & 0.02 & {[} & 0.88 & , & 0.94 & ] \\
\hline $100 \sigma_{m p}$ & Monetary policy & I & 0.10 & 1.00 & 0.22 & 0.01 & {[} & 0.20 & , & 0.25 & ] \\
\hline $100 \sigma_{z}$ & Neutral technology growth & I & 0.50 & 1.00 & 0.88 & 0.05 & {[} & 0.81 & , & 0.96 & ] \\
\hline $100 \sigma_{g}$ & Government spending & I & 0.50 & 1.00 & 0.35 & 0.02 & {[} & 0.33 & , & 0.38 & ] \\
\hline $100 \sigma_{\mu}$ & Investment & I & 0.50 & 1.00 & 6.03 & 0.96 & {[} & 4.71 & , & 7.86 & ] \\
\hline $100 \sigma_{p}$ & Price markup & I & 0.10 & 1.00 & 0.14 & 0.01 & {[} & 0.12 & , & 0.17 & ] \\
\hline $100 \sigma_{w}$ & Wage markup & I & 0.10 & 1.00 & 0.20 & 0.02 & {[} & 0.18 & , & 0.24 & ] \\
\hline $100 \sigma_{b}$ & Intertemporal preference & I & 0.10 & 1.00 & 0.04 & 0.00 & {[} & 0.03 & , & 0.04 & ] \\
\hline \multicolumn{5}{|c|}{ (log) Likelihood at median } & \multicolumn{7}{|c|}{-1072.8} \\
\hline
\end{tabular}

\footnotetext{
${ }^{1} \mathrm{~N}$ stands for Normal, B Beta, G Gamma and I Inverted-Gamma1 distribution

${ }^{2}$ Median and posterior percentiles from 3 chains of 120,000 draws generated using a Random walk Metropolis algorithm. We discard the initial 20,000 and retain one every 10 subsequent draws.
} 
Table 2: Posterior variance decomposition at business cycle frequencies in the baseline model ${ }^{1}$

Medians and [5th,95th] percentiles

\begin{tabular}{|c|c|c|c|c|c|c|c|}
\hline Series $\backslash$ Shock & Policy & Neutral & Government & Investment & Price mark-up & Wage mark-up & Preference \\
\hline \multirow[t]{2}{*}{ Output } & 0.05 & 0.25 & 0.02 & 0.50 & 0.05 & 0.05 & 0.07 \\
\hline & {$[0.03,0.08]$} & {$[0.19,0.33]$} & {$[0.01,0.02]$} & {$[0.42,0.59]$} & {$[0.03,0.07]$} & {$[0.03,0.08]$} & {$[0.05,0.10]$} \\
\hline \multirow[t]{2}{*}{ Consumption } & 0.02 & 0.26 & 0.02 & 0.09 & 0.01 & 0.07 & 0.52 \\
\hline & {$[0.01,0.04]$} & {$[0.20,0.32]$} & {$[0.02,0.03]$} & {$[0.04,0.16]$} & {$[0.00,0.01]$} & {$[0.04,0.12]$} & {$[0.42,0.61]$} \\
\hline \multirow[t]{2}{*}{ Investment } & 0.03 & 0.06 & 0.00 & 0.83 & 0.04 & 0.01 & 0.02 \\
\hline & {$[0.02,0.04]$} & {$[0.04,0.10]$} & {$[0.00,0.00]$} & {$[0.76,0.89]$} & {$[0.02,0.06]$} & {$[0.01,0.02]$} & {$[0.01,0.04]$} \\
\hline \multirow[t]{2}{*}{ Hours } & 0.07 & 0.1 & 0.02 & 0.59 & 0.06 & 0.07 & 0.08 \\
\hline & {$[0.04,0.10]$} & {$[0.08,0.13]$} & {$[0.02,0.03]$} & {$[0.52,0.66]$} & {$[0.04,0.09]$} & {$[0.04,0.11]$} & {$[0.06,0.12]$} \\
\hline \multirow[t]{2}{*}{ Wages } & 0.00 & 0.4 & 0.00 & 0.04 & 0.31 & 0.23 & 0.00 \\
\hline & {$[0.00,0.01]$} & {$[0.30,0.52]$} & {$[0.00,0.00]$} & {$[0.02,0.07]$} & {$[0.23,0.41]$} & {$[0.16,0.32]$} & {$[0.00,0.01]$} \\
\hline \multirow[t]{2}{*}{ Inflation } & 0.03 & 0.14 & 0.00 & 0.06 & 0.39 & 0.34 & 0.02 \\
\hline & {$[0.02,0.06]$} & {$[0.09,0.21]$} & {$[0.00,0.00]$} & {$[0.02,0.13]$} & {$[0.29,0.50]$} & {$[0.26,0.42]$} & {$[0.01,0.04]$} \\
\hline \multirow[t]{2}{*}{ Interest Rates } & 0.17 & 0.09 & 0.01 & 0.47 & 0.05 & 0.04 & 0.16 \\
\hline & {$[0.13,0.22]$} & {$[0.06,0.12]$} & {$[0.00,0.01]$} & {$[0.37,0.56]$} & {$[0.03,0.07]$} & {$[0.03,0.07]$} & {$[0.11,0.23]$} \\
\hline
\end{tabular}


Table 3: Variance share of output and hours at business cycles frequencies ${ }^{1}$ due to investment shocks, comparison with Smets and Wouters

\begin{tabular}{|c|c|c|c|c|c|}
\hline Model & $\begin{array}{l}\text { Smets and } \\
\text { Wouters }\end{array}$ & \multicolumn{3}{|c|}{ Ours } & \multirow{2}{*}{$\begin{array}{c}\begin{array}{c}\text { Durables in } \\
\text { Home }\end{array} \\
\text { Production } \\
\\
\text { Baseline with } \\
\text { consumption of } \\
\text { durable goods } \\
\text { observable }\end{array}$} \\
\hline $\begin{array}{l}\text { Definition of } \\
\text { observables }\end{array}$ & $\begin{array}{l}\text { Smets and } \\
\text { Wouters }\end{array}$ & $\begin{array}{c}\text { Smets and } \\
\text { Wouters }\end{array}$ & $\begin{array}{c}\text { Investment } \\
\text { includes } \\
\text { consumer } \\
\text { durables but not } \\
\text { inventories }\end{array}$ & Baseline & \\
\hline \multicolumn{6}{|l|}{ Series } \\
\hline Output & 0.23 & 0.19 & 0.42 & 0.50 & 0.65 \\
\hline Hours & 0.26 & 0.22 & 0.47 & 0.59 & 0.74 \\
\hline
\end{tabular}


Table 4: Variance share of output and hours at business cycle frequencies ${ }^{1}$ due to investment shocks, restricted models

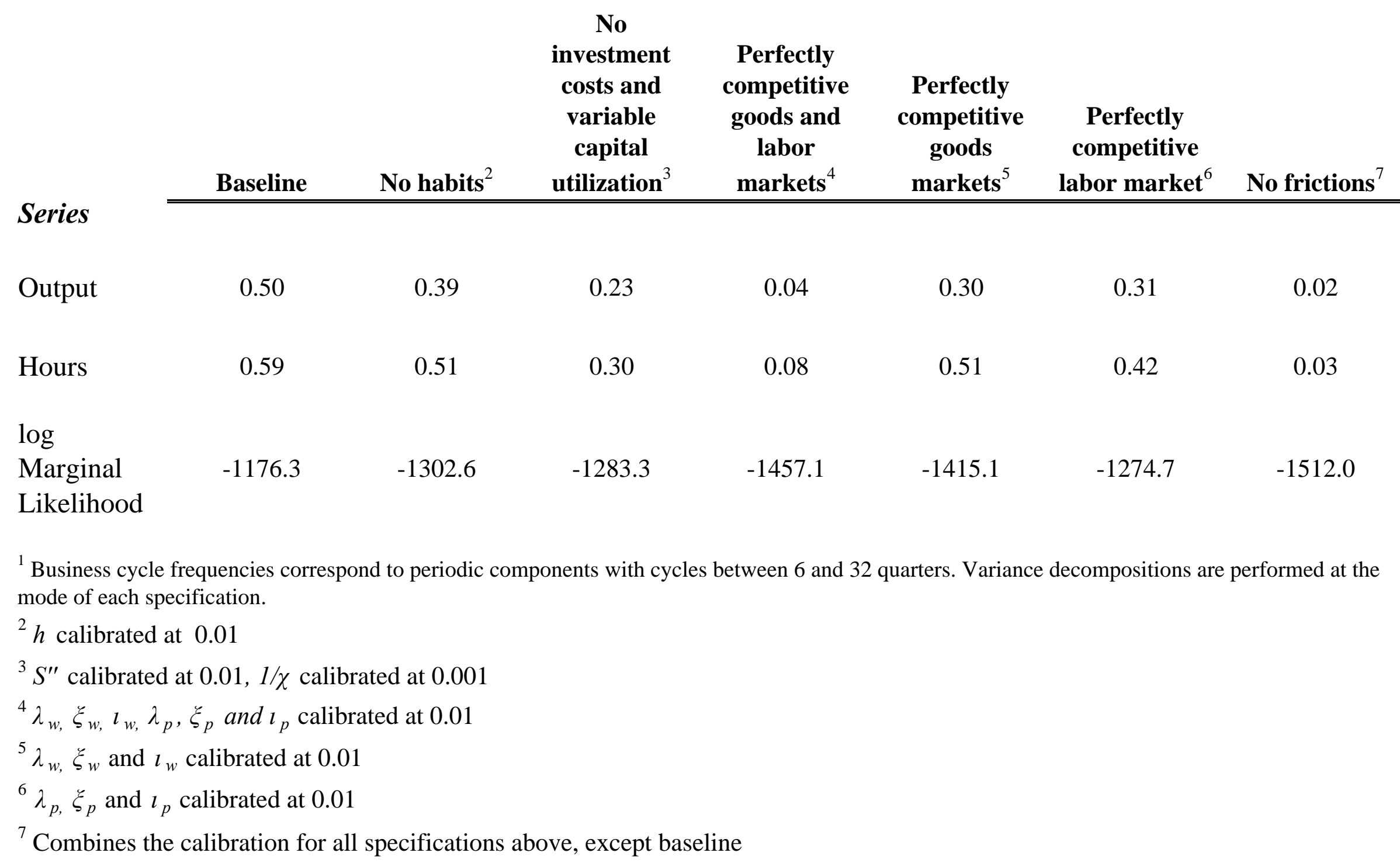


Table 5: Variance share of output and hours at business cycles frequencies ${ }^{1}$ due to investment shocks, robustness

\begin{tabular}{|c|c|c|c|c|c|}
\hline & Baseline & $\begin{array}{l}v=1 \text { and } \\
\alpha=0.3\end{array}$ & $\begin{array}{c}\text { No MA } \\
\text { components }^{2}\end{array}$ & $\begin{array}{c}\text { Taylor rule } \\
\text { with output } \\
\text { growth }^{3}\end{array}$ & MLE $^{4}$ \\
\hline \multicolumn{6}{|l|}{ Series } \\
\hline Output & 0.50 & 0.63 & 0.54 & 0.47 & 0.59 \\
\hline Hours & 0.59 & 0.75 & 0.56 & 0.52 & 0.65 \\
\hline \multicolumn{6}{|c|}{$\begin{array}{l}{ }^{1} \text { Business cycle frequencies correspond to periodic components with cycles between } 6 \text { and } 32 \\
\text { quarters. Variance decompositions are performed at the mode of each specification. }\end{array}$} \\
\hline \multicolumn{6}{|c|}{${ }^{2}$ Moving average component for price and wage mark-up shocks calibrated to zero. } \\
\hline \multicolumn{6}{|c|}{${ }^{3}$ Taylor rule responds to observable output growth instead of the output gap. } \\
\hline${ }^{4}$ Baseli & cification est & by maximur & elihood. & & \\
\hline
\end{tabular}


Figure 1: Year-to-year output growth, data and counterfactual with investment shocks

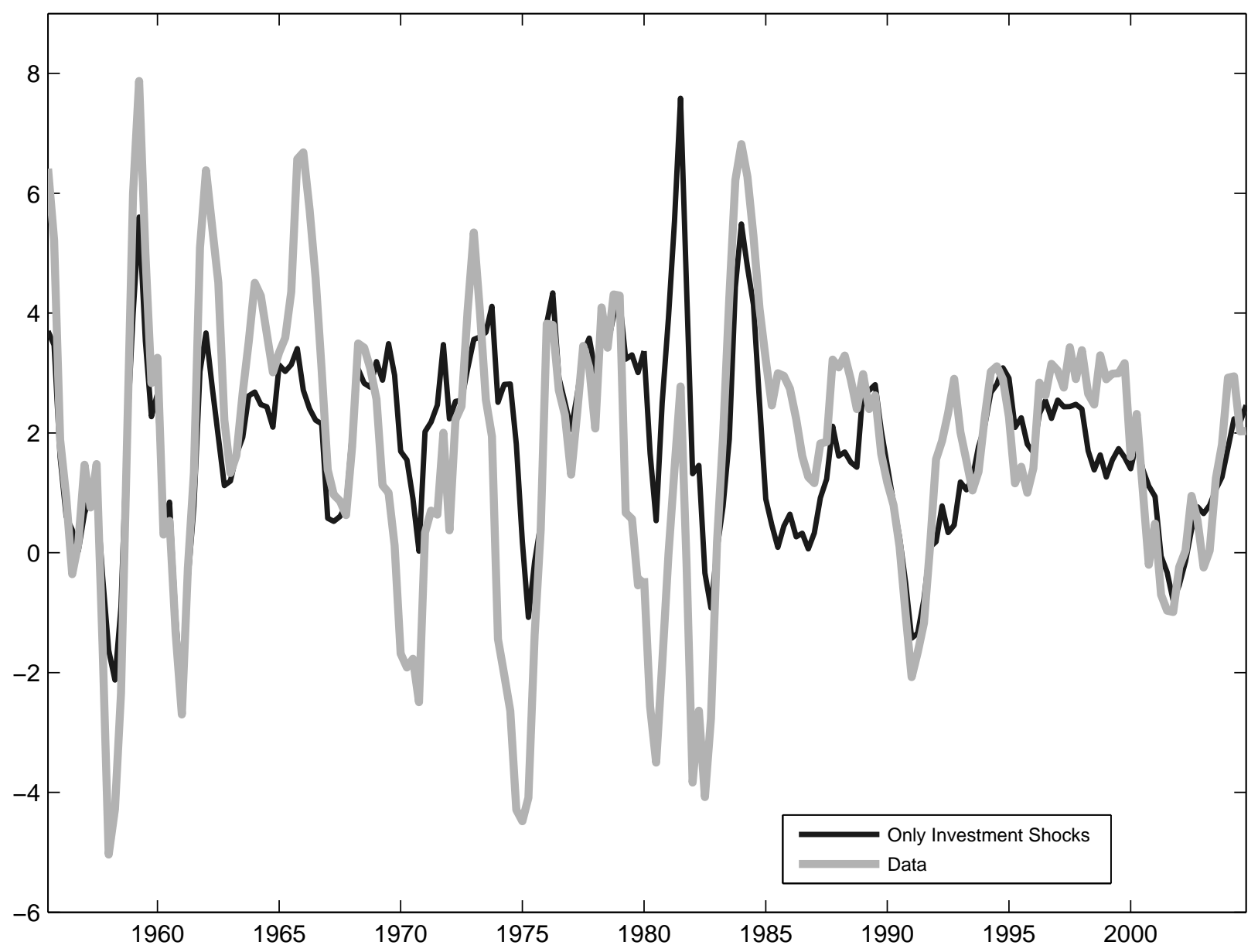


Figure 2: Variance share of hours explained by wage markup shocks at all frequencies

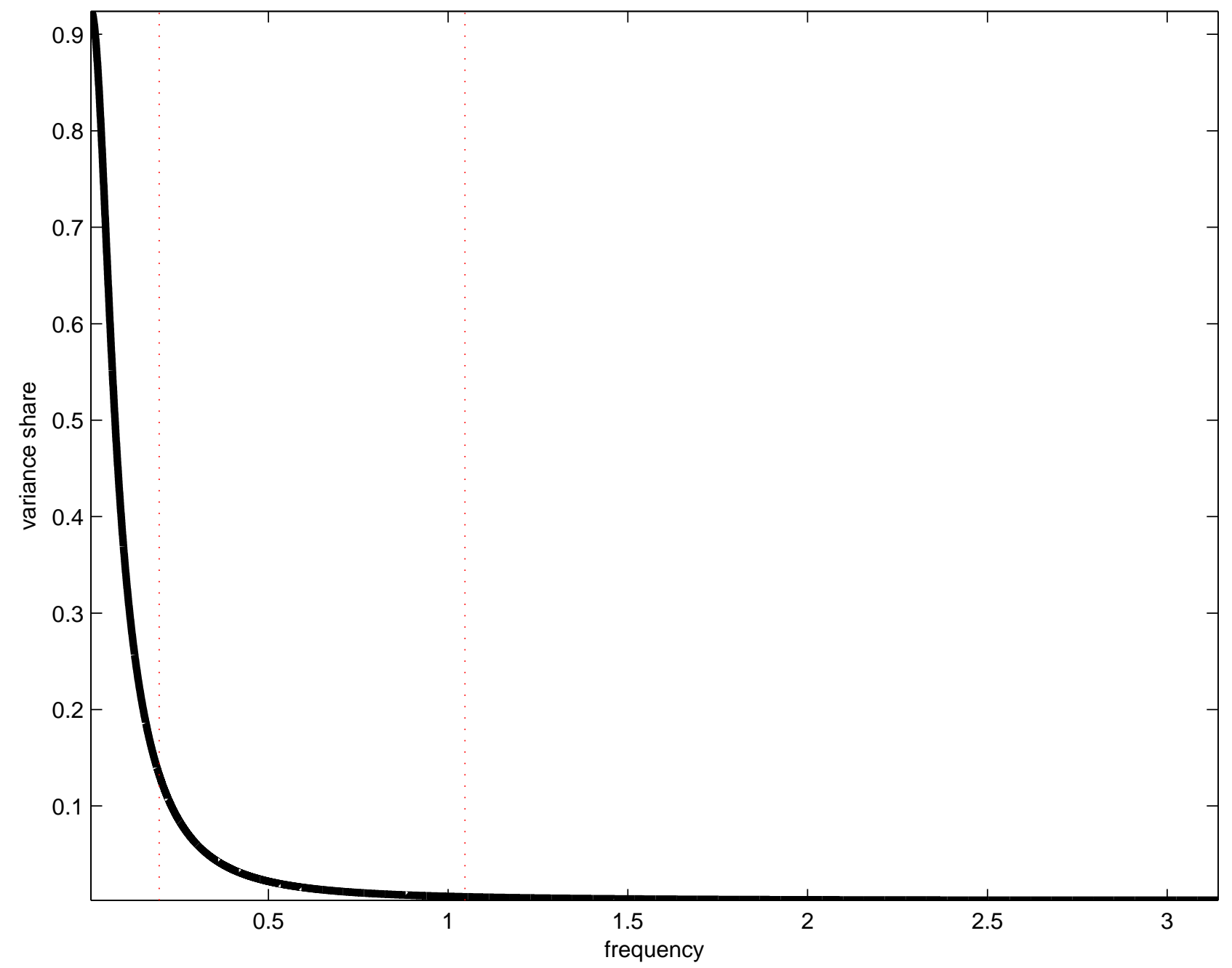

Vertical dashed lines mark the frequency band associated with business cycles of 6 to 32 quarters 
Figure 3: Impulse responses to a one standard deviation investment shock
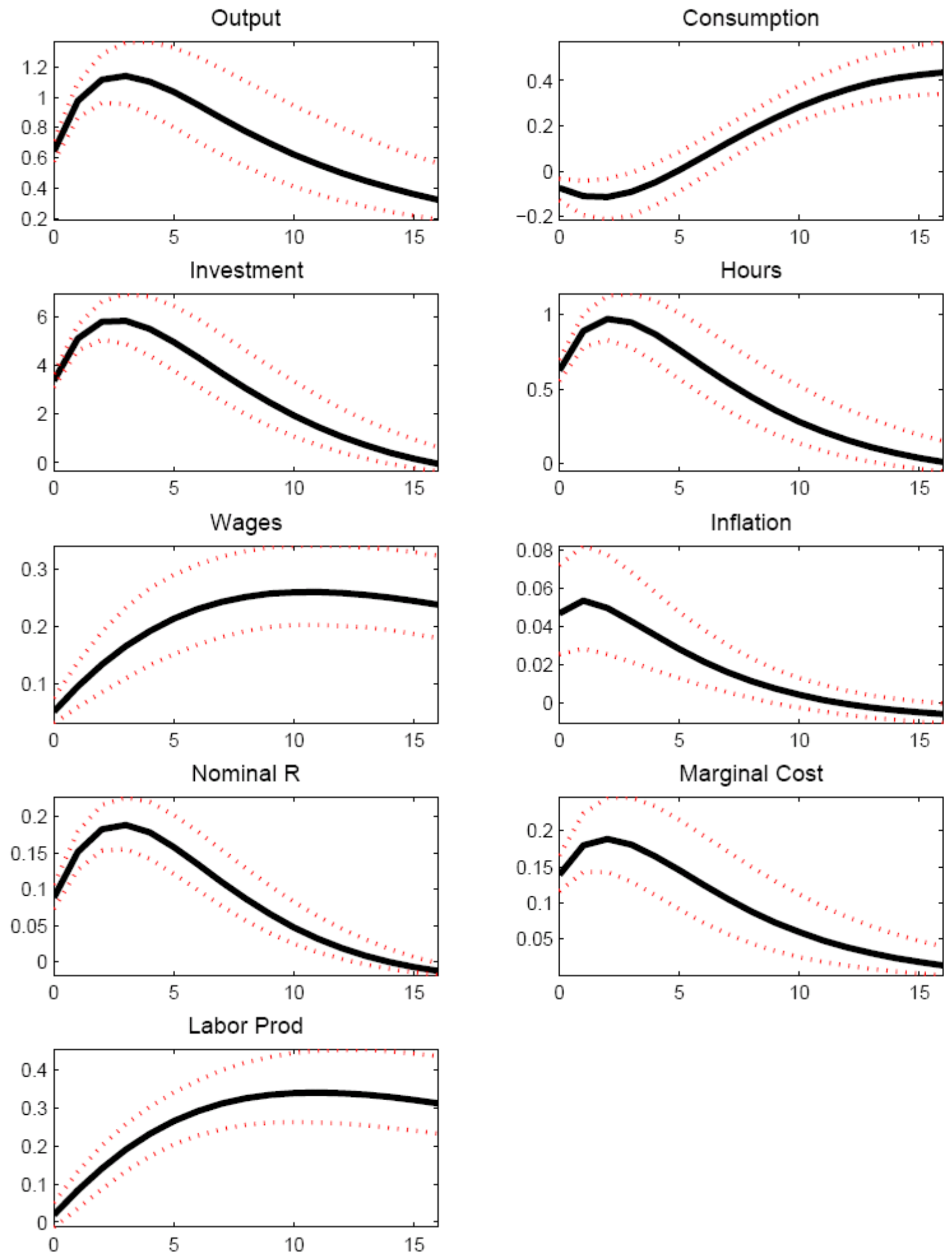